Journal of Teacher Education for Sustainability, vol. 21, no. 1, pp. 5-34, 2019

\title{
Journal of Teacher Education for Sustainability after the UN Decade of Education for Sustainable Development: Exploring for the Future
}

\author{
Anita Pipere \\ Daugavpils University, Daugavpils, Latvia
}

\begin{abstract}
This study aims to explore the research orientation of the papers published in the Journal of Teacher Education for Sustainability (JTES) immediately after the UN Decade of ESD (2015-2018). Through following the guidelines of bibliometric study and literature review, and by grounding on the deductive qualitative and quantitative content analysis, the paper presents the analysis of the main bibliometric indicators and research paradigms in the papers published in JTES. Moreover, the changes in these indicators and paradigms in comparison with those encountered in JTES from 2005 to 2014 were recorded and critically inspected. In general, the study shows the gradual improvement and development of main bibliometric indicators and research paradigms in last four years of JTES. The main recommendations and suggestions provided in the previous study have been implemented and considered in the Journal's general features and published papers, though, the current exploration indicates also some unrealized potential for improvement. At the end of paper the author states the main conclusions, limitations, suggestions for the further research and prospective development of the Journal, as well as some implications for the potential authors of JTES.
\end{abstract}

Keywords: bibliometric indicators, ESD, JTES, research paradigm, teacher education.

Exploring for the Future is a $\$ 100.5$ million initiative by the Australian Government dedicated to boosting investment in resource exploration in Australia. The four-year program led by Geoscience Australia focuses on northern Australia and parts of South Australia to gather new data and information about the potential mineral, energy and groundwater resources concealed beneath the surface. With incomparably smaller resources the Journal of Teacher Education for Sustainability (JTES) continues its global mission after the end of United Nations Decade of Education for Sustainable Development (UN DESD), publishing papers ultimately exploring for the future of human civilization and planet Earth. This paper is conceived as another exercise in developing insight for the research advancement in the field of teacher education (TE) for sustainability over the four-year period of publications in JTES (2015-2018). 
This is the fourth publication on the development of JTES: The reflections on the Journal started with the short vignette in UNESCO guidelines at the beginning of the Decade (2005), followed by presentation of JTES as the TE institution's good practice in the field of education for sustainable development (ESD) (Salite \& Pipere, 2007). The third publication presented an extensive review of the research field and bibliometric analysis of JTES during the UN DESD (Pipere, Veisson, \& Salite, 2015). The currently presented paper in terms of its content and structure is intended as the follow-up and to some extent also the methodological replication of the previous paper. The difference between these articles lays mainly in theoretical background and interpretation of results. Since the previous paper contained the extensive introduction to the establishment and maintenance of JTES, as well as the detailed insight into the research field of TE for $\mathrm{ESD} /$ sustainability, this information will be omitted in the present paper. In relation to the interpretative part of presentation, considering the fact that the currently reviewed period is almost twice shorter than the previous one, the author will not focus on the internal dynamics of development within the analysed four-year period.

Regarding the institutional context of JTES, it needs to be mentioned that the agreement concerning the establishment of UNESCO Chair on Teacher Education and Continuing Education: Interplay of Tradition and Innovation in Education for Sustainable Development at Daugavpils University was signed between the United Nations Educational, Scientific and Cultural Organization and Daugavpils University on July 15, 2013. Professor Ilga Salite was designated as the head of UNESCO Chair. Since the second part of 2015 JTES has become officially approved periodical of UNESCO Chair on Teacher Education and Continuing Education.

To ground the necessity for the presented study, the context of important global events should be addressed at the outset. The reviewed period of time covers the first years immediately after the end of UN DESD. Therefore, the "institutionalized and formalized"global boost for ESD research has come to the end and now it is important to learn what kind of changes have emerged in content and research approaches of JTES' authors, what kind of transformation in thinking of researchers and practitioners can be noticed, if any, in these first post-DESD years in order to keep track of the situation in the field. Since the main goal of JTES still reads as the need to develop quality research in the field of TE for sustainability, the editorial team of JTES needs to monitor the deviations from good quality, evaluate the success, identify still persisting and newly appeared problems, provide up-to-date recommendations for the further development of JTES.

While the regular reviews on JTES may help to fill the gap in studies summarizing the advances in research paradigms and trends of TE for sustainability, the review for the respective professional field has been recently authored by MacKeown and Hopkins (2014). Their paper describes the leading edge of ESD in the realm of TE at the end of the UN DESD. This contribution contains the analysis based on the academic literature and documents as well as 50 responses to survey questions elicited by experts in the field of ESD working at TE institutions representing 44 countries. The Appendix containing the list of respondents includes three responses from Daugavpils University (Latvia), one of which outlined activities of the Baltic \& Black Sea Circle Consortium (BBCC), one of the JTES, and one of the University. Some of the conclusions provided in this paper are well atuned to the context of the present paper. For instance, to analyse both professional practice and research in the area of TE, one has to acknowledge the situation 
that TE is performed differently in different parts of the world. This also relates to the contents and forms of the research on TE, although, probably at a smaller rate, since the global academic community of educational researchers, due to more or less similar institutionalization and peer-review processes, are not so disparate in their research practice as teaching professionals in the given field. However, "the reviewers of articles on TE for sustainability have to consider and carefully deal with the diversity of research coming from different parts of the world caused by the distinct cultural and historical background and institutional discourse" (Pipere et al., 2015). Furthermore, the greater diversity of countries represented in the Journal is bound to larger problems for editorsin-chief and reviewers in monitoring the virtue of submissions and presenting the balanced quality of papers in each volume of the Journal.

According to MacKeown and Hopkins (2014), TE institutions have to move from localized to wide-scale implementation of ESD now. As it was already denoted four years ago, "larger-scale comparative studies providing system-wide and policy-oriented evidence, although hard to conduct, would be necessary to develop the field" (Pipere et al., 2015, p. 15). Thus, TE research should be definitely oriented towards this movement after the UN DESD. However, it seems that now it has become even more utopian vision.

ESD in the field of TE moved from awareness raising to capacity building and finally it finished with efficacious implementation of good ESD practices. Since the beginning of UNESCO Global Action Programme (GAP) (UNESCO, 2014) and the involvement of the new TE institutions and researchers in this movement toward ESD, the research outcomes can be related to all three dimensions mentioned above. Nevertheless, because of more than a decade long global experience, the case studies presenting the analysis of good ESD practices would probably be presented in larger numbers.

\section{Conceptual Approaches to the Interpretation of JTES (2015-2018)}

The idea to concieve this paper partly came from the obligation to inspect the implementation of six recommendations elicited from the previous study (JTES 2004-2015) for the further development of JTES, namely, to:

- Deal with the diversity of research coming from different parts of the world and preserve its specific individuality while maintaining the high standards of academic writing,

- Increase the amount of large-scale multi-national, multi-institutional and multidisciplinary research,

- Improve the overall quality of publications paying particular attention to the methodological dimensions of contributions,

- Strengthen the Editorial Board of JTES by inviting several experts in the research methodology of educational research and teacher education,

- Respond to the call from the UNESCO GAP (UNESCO, 2014) to focus research on issues not fully resolved or even increasing during DESD,

- Decrease the number of papers only marginally connected with TE for sustainability (Pipere et al., 2015, p. 34).

Using the selected methodological approaches, this paper will provide answers about these six points demonstrating both the success in dealing with problems and some dimensions of the Journal development lacking the progress yet. 
Regarding the fifth recommendation - the call from the Global Action Program on ESD (UNESCO, 2014) to explore the issues emerging during the DESD, all five priority action areas, including, 1) to advance the policy, 2) to transform the learning and training environments, 3) to build the capacities of educators and trainers, 4) to empower and mobilize youth, and 5) to accelerate sustainable solutions at local level, will be used to classify the analysed papers by their topics.

Moreover, based on the previous paper (Pipere et al., 2015), processes which are necessary for effective ESD (Tilbury, 2011), i.e., collaboration, dialogue, whole system engagement, curriculum innovation, teaching/learning and active/participatory learning would be searched for the theoretical background and/or methodological elaborations of analysed papers. This analysis was not provided in detail in foregoing paper because of length limitations; however, the present paper used these processes as the deductive framework for the scope of research topics.

In the present study, a particular emphasis was given to the philosophical framework of papers, as "researchers working in the field of TE for sustainability should carefully follow the latest events in terms of the conceptual development of ESD/sustainability, recent discussions on educational theories and philosophical approaches in education" (Pipere et al., 2015, pp.15-16). Grounding on the outcomes of the previous analysis, the terms of holistic theory, complexity and anthropocentric/non-anthropocentric divide were searched in the present analysis; nevertheless, the new theoretical trends and approaches were "fished" for, too.

Similarly, as in the previous study (Pipere et al., 2015), the research papers published in JTES (2015-2018) will be classified by their genre using the taxonomy of TE research by Borko, Liston, and Whitcomb (2007) in which the papers will be identified as containing the effects of research, interpretative research, participant research, or design research. The effects of research is based on quantitative inquiry and uses experiments, quasiexperiments and correlational research. This research genre can be used to design and evaluate TE programmes, as well as, any interventions related to TE in terms of ESD. Interpretative research represents the qualitative inquiry exploring the specific situation from the perspectives of participants. In the context of TE this research genre tries to explain the sociocultural processes in natural settings related to TE. Moreover, it aims to improve professional practice, describe the results of policy enactment, and shape the theoretical development of TE. The participant research can be seen as part of interpretative research as it is "conducted by those who do the work of TE in order to understand and improve practice within a local context; therefore, blurring the boundaries between research, practice and improving the practice of TE" (Pipere et al., 2015, p. 11). This research genre presupposes the implementation of action research, participatory research, self-study and teacher research. The last genre is design research maintaining the strong connection between the improvement of practice and development of theory. For instance, an educational environment can be designed and enacted for pre-service teachers and the development of future teachers can be explored within this specific environment. Such a research study does not focus on the design of generalizable products (programs, devices, interventions, etc.), but its focus is on the constant adaptation of TE process in line with assessment of individual and collective activity (Borko et al., 2007).

Other framework used for the classification of papers will be based on research type, first of all, exploring the proportions of theoretical elaborations and empirical research. It is an obvious trend that for academic community, policy makers and practi- 
tioners empirical research grounding evidence-based practice seems to be more valuable than theoretical work. However, during the times of transformation and change, especially in case of specific fields of research like TE for ESD, such theoretical contributions are really indispensable to summarize the previous theoretical paradigms or inspire the further theoretical development of the discipline. Though, evaluating the theoretical papers we should certainly follow the suggestions by MacKenzie (2003) that "without well-developed construct definitions, it is impossible to develop a coherent theory because constructs are the building blocks of theory" (p. 324). It is especially important for the theoretical development of research areas like TE and the field of ESD. However, the researchers were caught in certain contradiction. Since the term of ESD suffers from the lack of clear definition and due to time of context and time dependent nature of sustainable development (SD), ESD would succeed paradoxically both from reducing vagueness and maintaining its ambiguity (Eernstman \& Wals, 2013).

To continue with delineation of research types and, focusing specifically on the research methodology of empirical papers, the educational researchers most likely will accept to divide them into quantitative, qualitative and mixed methods research. According to Sleeter (2014), one of the features of TE research capable of informing policy is that it "combines methodologies that include both quantitative and qualitative data, enabling policymakers to "see" how a program or practice might interface with local realities while also enabling them to assess its impact in clear terms" (p. 2). For this reason the special attention in the present analysis was given to the "quantity and quality" of mixed methods research.

Following the previously stated theoretical idea about the semantic waves manifested in the meaning of accumulated knowledge and once again searching for the semantic gravity and semantic density in the published set of papers, some features of Legitimation Code theory (Maton, 2014) need to shortly be sketched. According to this theory, all knowledge can be exibited in semantic waves that show the strengthening and weakening processes in relation to contextual dependence of knowledge and the concentration of meaning, thus, this theory "uses codes of semantic gravity that refer to the degree of abstraction or degree to which meaning relates to context and semantic density that refers to the degree of the growth in complexity or of the concentration of meaning within practices" (Pipere et al., 2015, p. 32).

\section{Methodology}

The methodological approach applied in this paper merges the bibliometric study with different forms of literature review. Similarly as in the previous study (Pipere et al., 2015), this exploration was based on the methodology of bibliometrics focusing on the single periodical - Journal of Teacher Education for Sustainability published by the UNESCO Chair on the Interplay of Tradition and Innovation in Education for Sustainable Development at Daugavpils University, Latvia, after the UNESCO Decade of ESD (20152018). Bibliometric analysis of single periodical can provide a deep insight and very detailed portrayal of a set of published submissions in the given field of academic research (Regolini \& Jannes-Ober, 2013; Thanuskodi, 2010). Considering the much smaller number of analysed volumes in comparison with previous exploration, several less important characteristics of the Journal would be omitted, while some elements will be emphasized more. Following the analytical framework of bibliometric measures by Kevin, Zainab, 
and Anuar (2009) as well as several common variables included in bibliometric studies (Regolini \& Jannes-Ober, 2013; Wright \& Pullen, 2007), the overview of qualitative and quantitative bibliometric results will include 1) the Journal's impact and databases, 2) representation of countries, institutions, authors, citation rate, 3 ) philosophical background, 4) keywords and topics, and 5 ) methodological features of the papers.

Some aspects of the presented study resemble the literature review, as this paper will compare the results of the previous study on certain issue (namely, JTES) with the current situation in this Journal, trying to distinguish emerging trends and issues in TE for sustainability. Given study also significantly aligns with the features of integrative review. Torraco (2005) states that this type of review "is a form of research that reviews, critiques, and synthesizes representative literature on a topic in an integrated way such that new frameworks and perspectives on the topic are generated" (p. 356). To accomplish these goals the patterns, similarities and differences among the articles within the sample (65 JTES papers) will be determined. Using a framework for integrative review developed by Whittemore and Knafl (2005), retained articles were read three times to determine the quality of the writing, to reduce and compare data within the articles and to analyze and synthesize themes and patterns within the literature sample. Besides, some aspects of this study will follow the discourse of methodological review, since the papers from JTES will be analysed also in terms of research approaches, methods of data collection and analysis (Fink, 2009; Petticrew \& Roberts, 2009).

Quantitative bibliometric data analysis was performed by simple counting or labelling procedures making inferrences about the existence or frequency of respective variables: the indicators of Journal's impact, databases, number of contributions per volume, representation of countries, institutions, authors, co-authorship patterns, citation rate, data analysis methods, etc.

In order to perform the analysis in terms of research paradigms, discerning the philosophical background of the studies, qualitative bibliometric analysis was merged with the deductive coding approaches in the context of qualitative content analysis of textual data. To interpret the philosophical background of published articles, deductive coding was based on the theoretical approaches invoked in the previous study (Pipere et al., 2015), also recording the novel features of philosophical underpinnings of the papers. The novel methodological trait was the usage of quantitative content analysis in order to count the appearance of philosophical discourse and references to specific philosophical concepts in the selected set of papers (JTES 2015-2018).

To distinguish the groups of keywords, research topics, and certain methodological features (research type and genre), deductive coding was used to map these elements on the taxonomies provided in the previous study (Pipere et al., 2015). Besides, all changes and new elements were observed and recorded as well. In general, coding was performed using the semantic details from the title, keywords, abstract, and main part of papers and analysing them in the light of authors' academic experience and analysis of literature in the field of TE for sustainability.

As it has already been suggested above, the aim of this study is to explore the research orientation of the papers published in JTES immediately after the UN Decade of ESD (2015-2018) focusing on the main qualitative and quantitative bibliometric indicators and the research paradigms used. Three research questions will be answered in the following presentation: 
1) What changes can be observed in the main bibliometric indicators of papers published in JTES (2015-2018) in comparison with the papers published in JTES (2005-2014)?

2) What changes can be observed in the research paradigms of papers published in JTES (2015-2018) in comparison with the papers published in JTES (20052014)?

3) How do these changes align with the recommendations and suggestions elaborated in the previous study (Pipere et al., 2015)?

\section{Corpus of the Study}

The present study targets the articles published in JTES from 2015 to 2018. The data pertaining to JTES includes 65 articles in seven issues starting from volume 17 in 2015 to volume 20 in 2018. The exploration of editorship for studied issues shows the large changes in the amount of editors and personalities in comparison with the previous period of analysis. The number of editors-in-chief has changed from one to four, besides, the new position of associate editor has been established instead of language editor (with similar functions) since 2017 . The first analysed issue $(17(1), 2015)$ was edited by Astrīda Skrinda (Daugavpils University); following issue (17(2), 2015) was edited by the guest editor Anita Pipere (Daugavpils University). Next five volumes were published under the guidance of Ilga Salite and Dzintra Iliško (Daugavpils University) in cooperation with several Iranian colleagues. Javad Gholami (Urmia University) was invited as the guest editor for the volume 18(2), (2016), while in volume 19(2) (2017) he joined the team of editors-in-chief. In 2018 (20(1)) one more Iranian scholar Hussein Meihami (Shiraz University) acceded the group of editors-in-chief. Moreover, the last four years of JTES have been particularly remarkable with regard to the quantitative and qualitative development of Editorial Board; about 20 new members have joined the team of peer reviewers, among them such internationally recognized academics as Charlotte Holland from Dublin City University (Ireland), Andreas Brunold from the University of Augsburg (Germany), Michele Biasutti from the University of Padova (Italy), Tomonori Ichinose from Miyagi University of Education (Japan) and many others.

\section{Results}

Main Bibliometric Indicators (JTES, 2015-2018)

Impact and databases. Although the number of databases representing JTES has not changed a lot in the past four years, the impact of journal has obviously increased, e.g. SCImage Journal Rank (SJR) has increased from 0.217 in 2014 to 0.313 in 2017, Source Normalized Impact per Paper (SNIP) has significantly rised from 0.256 to 1.335 . Impact per Publication in 2014 was 0.222, while recently introduced CiteScore in 2017 was 1.15 .

Representation of countries, institutions, authors, citation rate. The Journal still has two issues per year. The number of articles per volume in the targeted seven issues ranged from 6 to 11 articles -7.9 articles on average per issue (previously 7.7). The submitted papers have come from 29 countries representing all parts of the world. However, JTES maintains the imbalanced distribution of papers regarding the countries. Again, 
six countries have provided about $70 \%$ of total publications (Latvia $(32.3 \%)$, Iran $(10.8 \%)$, Lithuania $(7.7 \%)$, Estonia (6.2\%), Germany (4.6\%), Finland (4.6\%)). Canada, Japan, Jordan, Slovakia, Spain, Turkey and the USA each have been represented by two papers $(3.1 \%)$. Other countries (Australia, Colombia, Fiji, Indonesia, Ireland, Italy, Malta, Namibia, the Netherlands, Poland, Republic of Croatia, Saudi Arabia, Serbia, Singapure, South Africa, and Ukraine) have been represented by one paper each $(1.5 \%)$. The current distribution shows the trend toward redirecting the main focus of submissions from the North of Europe to the Central and Southern part of Europe, as well as to the Middle East. Besides, the scope of the countries has been maintained and somewhat extended in these past four years (from 26 to 29 countries). Six papers were authored by scholars from different countries $-9.2 \%$ (about three times more than in the previous period). Ten papers were written by the representatives of different institutions within a single country, thus manifesting the growing trend of inter-institutional dialogue.

Moreover, new transdisciplinary turn has been noticed not only in philosophical background of the papers (see the next section of the paper), but also in six papers whose authors represented, using the terminology of transdisciplinary paradigm, different types of stakeholders (Mauser et al., 2013). Thus, in paper by Geng, Midford, and Buckworth (2015) the stress level of pre-service teachers during teaching practicum was explored in collaboration between the Charles Darwin University academics and representative from the Menzies School of Health. The author of the paper on the teacher ecological self Rea Raus (2016) represents both the academic institution and NGO (University of Tampere and Statera Research and Practice Center for Sustainability), while Bikse and her colleagues from Latvia (2016), who analysed the transformation of universities toward entrepreneurial universities, are academics from two universities and BA School of Business and Finance. Stanzus with colleagues (2017), describing the development of a consumption-specific intervention based on mindfulness training, represent two universities, two mindfulness research institutes and the European Centre for Mindfulness, therefore, designating the fruitful cooperation of different disciplines and practitioners in this transdisciplinary field. Two more papers are written by partners from university and public schools in South Africa (Okeke \& Mtyuda, 2017) and the USA (Lekunze \& Strom, 2017).

The leading institution with 11 papers $(16.9 \%)$ published in JTES from 2015 to 2018 again was Daugavpils University, besides, also the representatives from eight other higher education institutions from Latvia lately have found this possibility more attractive $(7.7 \%)$. From all 155 authors of 65 papers $57(36.8 \%)$ were men that aligned with the world-wide trend of female domination in education system and also in educational research. About one quarter (39.9\% in the previous period) of articles were written by a single author, other papers were authored by two to nine authors - average number of authors per paper was about 2.3 during the analysed period.

In a period from 2015 to 2018 , only $23(35.4 \%$ ) papers have not been cited yet (in majority from the most recent volumes). Three papers that have received the largest citation rate by April 2019 in SCOPUS are authored by Pipere et al. (2015) (15 citations), Bell (2016) (14 citations), Salīte, Drelinga, Iliško, Oḷehnoviča, \& Zariņa (2016) (12 citations). In comparison with the previous period, when only $24.6 \%$ of papers were cited at least once, this is quite impressive increase signifying the global relevance of the publications in JTES. 


\section{Research Paradigms (JTES, 2015-2018)}

Philosophical background of the papers. This overview will focus on a deeper analysis of the theoretical (philosophical) discourse during the last four years of JTES, particularly looking for changes in the themes already found in the previous period of JTES (2005-2014), namely, holism, complexity, anthropocentric/non-anthropocentric divide, humanistic philosphy, as well as searching for the new trends. Following the reporting style of both qualitative and quantitative content analysis, numbers and citations from the papers will serve as illustration for the author's argumentation.

Detailed exploration of the content of the articles shows that many authors admit the necessity to refer to some philosophical concepts or theory. However, not all of them elaborate on this philosophical discourse. The analysis of the papers proves that 26 $(40 \%)$ papers comprise some references to philosophical concepts, theories and approaches similar to those applied in previous volumes of JTES or new ones. This testifies the significant increase in comparison with the previous analysis in years 2005-2014, when only $25 \%$ of papers contained some philosophical treatise of the subject matter. However, in the present analysis only seven papers demonstrate the attempts of more or less extensive elaboration on these concepts, theories and approaches (Bojāre, 2016; Bojāre \& Skrinda, 2016; Fedosejeva, Boče, Romanova, Iliško, \& Ivanova, 2018; Jurgena, Cēdere, \& Keviša, 2018; Pipere et al., 2015; Raus, 2016; Salīte, Drelinga, Iliško, Oḷehnoviča, \& Zarina, 2016). Against expectations almost all of these papers contained also some empirical research, indicating that these theoretical discourses mainly served as an extensive background for empirical research.

In further presentation, the current usage of terms already applied in earlier theoretical elaborations of JTES papers from 2005 to 2014 will be explained (holism, complexity, anthropocentric/non-anthropocentric divide, humanistic philosphy) as well as some newly introduced concepts will be reviewed.

Holism. From 26 papers that included philosophical underpinnings of theoretical analysis or empirical research, 23 papers (35.4\% from overall sample) contained the references to holism. This is a significant increase in comparison with $13.8 \%$ of papers in the previous study. The content analysis of the papers shows that this concept has been used most often in four lengthy papers, namely "Education for Sustainable Development: The Choice of Pedagogical Approaches and Methods for the Implementation of Pedagogical Tasks in the Anthropocene Age" by Fedosejeva et al. (2018) (54 times), "Autonomous Learning for English Acquisition in Blended E-studies for Adults within the Context of SD" by Bojāre (2016) (33 times), "Transformation of the System of Values of Autonomous Learning for English Acquisition in Blended E-studies for Adults: A Holistic Fractal Model" by Bojāre and Skrinda (2018) (31 time) and "Developing Research in Teacher Education for Sustainability: UN DESD via the Journal of Teacher Education for Sustainability" by Pipere et al. (2015) (28 times). Fedosejeva et al. (2018) write about "more holistic research", "more holistic view", "more holistic framework", etc., thus pointing toward the insufficiently holistic nature of these entities. In this paper the adjective "holistic" is used together with a wide scope of phenomena, like research, research framework, view, approach, understanding, framework, action, etc., although the main focus is on the holistic research framework for educational research in the context of ESD. In a similar vein Bojāre (2016) applies the concept of "holism" to a wide scope of various phenomena, however, the main focus of her paper is the holistic model of autonomous learning. Following the initiated trend, the same author with a 
co-author has published paper on a Holistic Fractal Model of value transformation in autonomous learning attaching "holism" to 18 different phenomena starting from the holistic system of values and ending with holistic approach and holistic properties. Programmatic paper by Pipere et al. (2015), describing the current situation in TE, ESD research and higher education for sustainability stresses the holistic approach to education as well as evaluates the usage of holistic theory and methodological holism in the papers of JTES.

Complexity. From 26 papers, including any references to the philosophical underpinnings of theoretical analysis or empirical research, half of them $(20 \%$ from overall sample) contained the references to complex phenomena or complexity, however, sometimes it was hard to discern if the authors have envisaged complexity as a theoretically grounded term or just used the adjective "complex" as the synonym for something manifold, entangled, heterogenous, confused etc. In comparison with $5.1 \%$ papers containing some elaborations on complexity in previously studied volumes of JTES, the increase of about four times in past four years shows the obvious interest of authors regarding this concept. The content analysis shows that terms "complex" or "complexity" have been used most often in three papers, e.g., "Developing Research in Teacher Education for Sustainability: UN DESD via the Journal of Teacher Education for Sustainability" by Pipere et al. (2015) (33 times), "Sustainability from the Transdisciplinary Perspective: An Action Research Strategy for Continuing Education Program Development” by Salite et al. (2016) (22 times) and "Education for Sustainable Development: The Choice of Pedagogical Approaches and Methods for the Implementation of Pedagogical Tasks in the Anthropocene Age" by Fedosejeva et al. (2018) (17 times). The creators or inspirers of these papers mostly have been the editors of JTES. Pipere et al. (2015) use the term "complexity theory" mainly in order to grasp the contemporary trends in educational research in general and in research related to TE for sustainability. Paper by Salite et al. (2016) activates much wider implications of complexity using it in 12 expressions like complexity approach, complex phenomena, complex issues, complex processes, complex sciences, etc. In this paper it is rather hard to pinpoint the specific target for the application of this phenomena as it is used both in terms of science, education, action research, issues to be dealt with in action research, etc. Fedosejeva et al. (2018) mostly use the terms "complex approach" and "complex phenomena" attributing them to different phenomena of the world and education.

Anthropocentric/non-anthropocentric divide. Explicit reference to the anthropocentric/non-anthropocentric divide or critique of anthropocentrism have been observed in four papers that shows a significant decrease from $15.4 \%$ in the first study to $6.2 \%$ in the current study. Pipere et al. (2015) mention it 14 times speaking about these terms as integrated in theoretical approaches for ESD research or TE for sustainability research. Raus (2016) refers to the anthropocentric orientation acknowledging that "our educational enterprise should change from being grounded in a techno-specialist, anthropocentric orientation toward an orientation, which is far more generalist and ecologically relevant" (p. 43). Salite et al. (2016) speak about the need for the detachment of science from anthropocentric impact on the global system, while Fedosejeva et al. (2018) indicate that "public support for the implementation of the ESD goals has increased, but the state of nature-human relations has remained under the dominant influence of anthropocentrism, egocentrism and currently apparent technocentrism” (p. 160). 
Humanistic philosophy. From all papers using the philosophical terminology only three papers relate to humanistic theory. Pipere et al. (2015) mention humanistic philosophy as the trend used by some authors of JTES papers, while Bojāre (2016) and Bojāre and Skrinda (2016), focusing on the model of autonomous learning, mention humanistic paradigm of society, humanistic theory of autonomous learning and humanistic approach to education.

Transdisciplinarity. Transdisciplinarity is the new concept gradually emerging in the evaluated papers from 2015 to 2018 . Eight papers (12.3\% from 65) integrate the idea of transdisciplinarity, while two papers contain the deeper elaboration on this topic. The content analysis of paper "The Prospects of Transdisciplinary Approach to Promote Learners Cognitive Interest in Natural Science for SD" by Jurgena, Cédere, and Keviša (2018) shows that the authors have used the term "transdisciplinarity" 31 time; the authors obviously try to suggest the foundations for their empiric research and scrupulously explain the transdisciplinary approach in the context of science and education, contextualizing this in the discourse of SD. Other paper containing "transdisciplinarity" in its title is "Sustainability from the Transdisciplinary Perspective: An Action Research Strategy for Continuing Education Program Development” by Salite et al. (2016). Thus, the authors pay a lot of attention to the discussion about the transdisciplinary approach to research. In this case they aim to build an advanced theoretical conceptualization for the empirical exploration related to a participatory action research strategy. Other authors mentioning transdisciplinarity once or twice (e.g., Bojāre \& Skrinda, 2016; Carbach \& Fisher, 2017; Fedosejeva et al., 2018; Mammadova, 2017; Pipere et al., 2015; Stašulāne, 2017) mainly apply this term speaking about transdisciplinary research, projects, field trip approach, etc.

Ontology. The set of analysed papers for the first time contained explicit references to the ontology (four papers). Two papers were championing in this regard both containing 13 references to this term embedded in different expressions or phrases. Raus (2016) in her theoretical paper "Modelling a Learning Journey towards Teacher Ecological Self" designates pedagogy as the science of being (ontology) and, trying to theoretically justify the need for teachers' ecological self, indicates that unsustainability should be tackled from the fundamental level of ontology. Fedosejeva et al. (2018) refer to ontology as a philosophical dimension and similarly focus on the ontological roots of pedagogy.

Single most extensive explanation of ideas from specific philosopher within the set of the analysed papers was Habermasian approach to citizenship, explicated in the paper "The Challenges of Global Citizenship for Worldview Education: The Perspective of Social Sustainability” by Miedema and Bertram-Troost (2015).

From all papers mentioned in this analysis only two papers represented some form of theoretical, conceptual papers or literature review (Miedema \& Bertram-Troost, 2015; Raus, 2016). At the same time several theoretical papers did not refer to the terms analysed above or any other philosophical terms (Álvarez-García, Sureda-Negre, \& Comas-Forgas, 2015; Bell, 2016; Krūmiņa \& L,ubenko, 2016; Reid \& Horváthová, 2016; Jirgensons \& Kapenieks, 2018).

Content of papers: keywords and topics. The keywords and topics of JTES papers (2015-2018) will be analysed both from the quantitative and qualitative points of view. In total, 65 articles contained 320 keywords. In comparison with the previous study the thematics of key words has considerably changed. Some groups of keywords from the previous analysis are still discernible, while others appeared at much smaller rate or 
were not found at all. In the studied papers the largest group of keywords $(n=67)$ signified the teacher training/education, activities and properties of teachers as well as the types of teachers. The keywords related to teacher training/education (e.g., pre-service teacher training, teacher education, in-service training, etc.) appeared 19 times, activities and properties of teachers (e.g., teacher efficacy, teachers' views, effective teaching, etc.) were mentioned 36 times, while types of teachers (e.g., EFL teachers, preschool teachers, novice teachers, student-teachers, etc.) were observed 12 times.

The other large group (63 keywords) contained the words or phrases related to ESD or SD. The term "education for sustainable development" was mentioned 11 times (the largest number among all keywords), the term "sustainability" appeared seven times, while the term "sustainable development" was mentioned six times. Also, some specific relationships with sustainability were displayed in keywords like "education for sustainable consumption", "sustainability reporting", "sustainable behaviour", "sustainable professional growth', "urban sustainability”, etc.

The next largest group of keywords $(n=52)$ was related to psychological processes/ phenomena connected with learning or behaving within educational environment. This group, which was not observed at all in the previous study, contained the terms that could be attributed to cognitive (e.g., knowledge, belief change, adaptive thinking, analogical thinking, conception, etc.), emotional (e.g., emotional competence, stress levels, etc.), and behavioural (e.g., conflict, bullying, behaviour changes, etc.) discourses.

The group of keywords reflecting the types of schools, students and education is much smaller $(\mathrm{n}=31)$ and this group mostly elucidates the research sample or research context. Types of school were mentioned 19 times, including higher education $(n=6)$, preschool $(\mathrm{n}=3)$, school $(\mathrm{n}=2)$, secondary school, primary school, etc. Different categories of students were mentioned six times (children from needy families, generation Z, youngsters, pupils, etc.). Types of education also were mentioned six times (value education, inclusive education, entrepreneurship education, etc.). In the previous study this group of keywords was much larger.

Next group of keywords pertains to the learning processes and outcomes $(n=18)$, this group also appeared for the first time and included the keywords depicting different types of learning (e.g., autonomous learning, transformative learning, social emotional learning, collaborative learning, self-directed learning, distance learning), different literacies and skills.

Similarly, as in the previous analysis (JTES 2005-2014) the group of keywords illustrating the research designs and methods described in the papers was rather small $(n=17)$. This group of keywords contained the terms related to quantitative research (e.g., quantitative framework, statistics, bibliometrics), qualitative studies (participatory action research, focus groups, teachers' authored narratives), and more integral research (integrated study, transdisciplinary approach, etc.).

Finally, the smallest group of keywords can be related to the area of ICT $(n=13)$ that demonstrates certain advance of ICT related papers in last four years of JTES. This group of terms included such keywords as digital media, digital citizenship, e-learning, blended e-studies, blockchain, etc.

Other keywords represented rather large and disparate group of concepts in connection with educational stakeholders and their actions, elements of teaching/learning approaches as well as keywords with general meaning (e.g., advantages, disadvantages, dynamics, practices, transformation, etc.). 
Regarding the topics of the analysed papers, they will be analysed deductively using three different frameworks: 1) classification of inductively detected topics described in paper by Pipere et al. (2015), 2) call from the UNESCO GAP (UNESCO, 2014) to explore the issues not fully resolved or even increasing during DESDS and 2) processes necessary for effective ESD (Tilbury, 2011) (collaboration, dialogue, whole system engagement, curriculum innovation, teaching/learning and active/participatory learning).

Unlike in the previous study (Pipere et al., 2015), the largest group of papers (18 or $27.7 \%$ ) in the current study relates to the professional development of pre-service/inservice teachers. This group is well represented by such papers as "Modelling a Learning Journey towards Teacher Ecological Self” (Raus, 2016), “Teacher Training Programs for Gifted Education with Focus on Sustainability” (Reid \& Horváthová, 2016) and "Education for Sustainable Development: The Choice of Pedagogical Approaches and Methods for the Implementation of Pedagogical Tasks in the Anthropocene Age" (Fedosejeva et al., 2018). Next topic (the most popular in the previous study), was related to the various school subjects and areas (8 or 12.3\%) like English as a foreign language, physics, mathematics, etc. This group can be illustrated by the papers "Using Analogies in Teaching Physics: A Study on Latvian Teachers Views and Experience" (Jonāne, 2015) and "The Prospects of Transdisciplinary Approach to Promote Learners Cognitive Interest in Natural Science for SD" (Jurgena, Cēdere, \& Keviša, 2018). Well-discernible topic revealing the teachers' views on different issues in education and ESD also was represented by eight papers, for instance, “A Suggested In-service Training Model Based on Turkish Preschool Teachers Conceptions for SD" (Kabadayi, 2016) and “An Analysis of Transformation of Teaching and Learning of Japanese Schools that Significantly Addressed Education for SD" (Ichinose, 2017). Little less prevalent group of papers that resembles the group observed in the previous study was papers describing school/educational environment, its issues and connection with ESD (six or 9.2\%). This group can be exemplified by the papers "Social Equality as Groundwork for Sustainable Schooling: The Free Lunch Issue" (Kairiene \& Sprindziunas, 2016) and "Gender Identity of Students and Teachers: Implications for a Sustainable Future” (Badjanova, Pipere, \& Iliško, 2017). Two papers adressed the preschool education theory and practice (e.g., "Value Education in Estonian Preschool Child Care Institutions" by Ulavere and Tammik, 2017); also the authors of two papers were dealing with theoretical issues and research in pre-service/in-service TE for ESD (e.g., "Environmental Education in Pre-service Teacher Training: A Literature Review of Existing Evidence” by Álvarez-García et al., 2015). The topics of curriculum development and TE program evaluation were represented by one paper each.

Seven papers $(10.8 \%)$ were hard to attribute to any group presented above as they did not contain references either to teachers or to the SD or sustainability. This number is little higher in comparison with the previous study $(7.2 \%)$, however, the findings that 22 papers $(33.8 \%)$ do not focus directly on teachers, while 26 papers $(40 \%)$ lack the pronounced connection with ESD or SD probably could serve as some warning sign for the Journal.

In terms of five priority areas of the Global Action Programme (GAP) on ESD (UNESCO, 2014), namely, advancing policy, transforming learning and training environments, building capacities of educators and trainers, empowering and mobilizing youth and accelerating sustainable solutions at local level, the area of capacity building for educators and trainers was represented by the largest number of papers $(n=27)$. This priority area can be illustrated by such papers as "Teacher Education for Sustainability: 
The Awareness and Responsibility for Sustainability Problems” (Anšię \& Tatalovię Vorkapię, 2017) and "Implementing Education for Sustainable Development in Namibia: School Teachers' Perceptions and Teaching Practices" (Anyolo, Karkkainen, \& Keinonen, 2018). The next largest area of GAP represented in JTES (2015-2018) concerned the transformation of learning and training environments $(n=20)$ as it was closely tied to the teaching discourse. This group can be illustrated by the papers related to technological environment (e.g., "Digital Citizenship in the Afterschool Space: Implications for Education for Sustainable Development" by Howard, 2015), social environment at school (e.g., "The Resolution of Conflict between Teacher and Student: Students' Narratives” by Ciuladiene \& Kairiene, 2017), cognitive environment (e.g., “The Relationship between Mathematics Teachers Teaching Approaches and $9^{\text {th }}$ Grade Students Mathematical Self” by Briede, 2016). At much less rate JTES has published papers related to acceleration of sustainable solutions at local level $(n=4)$. This group of contributions can be vividly illustrated by the paper authored by Mammadova (2017) "Education towards Urban Sustainability: Lessons Learned from the Welfare Business Models of Kanazawa City, Japan”. Papers concerning some issues pertained to the advancement of policy in relation to different aspects of SD $(n=3)$ can be represented by the paper "Twenty-first Century Education: Transformative Education for Sustainability and Responsible Citizenship" by Bell (2016), while two papers were related to the issues of empowering and mobilizing youth (e.g., "Human Securitability: A Participatory Action Research Study Involving Novice Teachers and Youngsters" by Kravale-Paulina and Ol̦ehnoviča, 2015). Thus, the charting of the topics of JTES (2015-2018) with the help of GAP demonstrates the good match between the content of papers and priority areas of this programme, since $86 \%$ of published papers corespond to one or another priority area.

Analysing the topics of 65 papers with the use of a deductive framework of processes necessary for effective ESD (Tilbury, 2011), one can notice a significantly lower level of alignment, since only about half of the papers $(n=28)$ matched some of these processes. The largest group of papers $(\mathrm{n}=17)$, as expected, related to the teaching/learning: within this group two papers contained the references to the active/participatory learning, namely, paper by Martinsone and Vilcina (2017) “Teachers' Perceptions of Sustainability of the Social Emotional Learning Program in Latvia: A Focus Group Study” as well as paper by Korsun (2017) “The Formation of Learners' Motivation to Study Physics in Terms of Sustainable Development of Education in Ukraine”. The next largest group, consisting of eight papers, can be associated to the whole system engagement. This concept resembles the holistic approach to the phenomena analysed in educational discourse, and, as mentioned above, 23 papers contained some references to holism. Looking for more detailed expressions of whole system engagement, it appeared that measuring sustainability competences (Besong \& Holland, 2015) or views on waste management (Kolbe, 2015), looking for more holistic approaches to education for sustainable consumption (Stanszus et al., 2017), analysing teachers' comments on ESD methods (Ichinose, 2017), or looking for the best appproaches to education for urban sustainability (Mammadova, 2017) one can notice the implications to the mental wholeness (cognitive and emotional sphere), educational integration (abilities, knowledge, attitudes, dispositions, behaviours, practices), and sustainability integration (social, environmental, economic sectors). On the other hand, some papers attained to the holistic research framework (e.g., Fedosejeva et al., 2018) can also be related to the whole system approach. The 
processes of collaboration and dialogue were well represented in two papers originated at Daugavpils University: Kravale-Pauliņa and Ol̦ehnoviča (2015) elaborated on the collaboration between the researchers, novice teachers and youth within participatory action research, while Salite et al. (2016) described the transdisciplinary participatory action research as a framework for cooperation between the university and its graduates. Only one paper referred to the curriculum innovation ("Assessing the Infusion of Sustainability Principles into University Curricula” by Biasutti, De Baz, \& Alshawa (2016)).

Methodological features. In this section the methodological features of the papers will be described, first, using the framework of research type, then by research genre (Borko et al., 2007). Looking back to the previous analysis, already detected problematic matters will be put in scope; also the new types of papers and the novel issues will be inspected.

Similarly as in the previous analysis, the majority of articles (49 or $75.4 \%$ ) represented some type of empirical papers, $9.2 \%$ of all papers integrated both novel theoretical ideas and empirical research (e.g., Šipilova, Ostrovska, Jermolajeva, Aleksejeva, \& Oḷehnovičs, 2017; Salìte et al., 2016), while $15.4 \%$ of papers were conceived as theoretical elaboration on different subjects (e.g., Álvarez-García et al., 2015; Miedema \& BertramTroost, 2015). With regard to the methodological priorities in empirical studies, exactly like in preceding exploration (Pipere et al., 2015), qualitative research was produced most often (29.2\% of papers) (e.g., Carbach \& Fischer, 2017; Ulavere \& Tammik, 2017), followed by quantitative studies (26.2\%) (e.g., Biasutti, De Baz, \& Alshawa, 2016; Eslamian, Jafari, \& Neyestani, 2017) and mixed methods research (20\%) (e.g., Briede, 2016; Jurgena, Cēdere, \& Keviša, 2018), showing certain increase in comparison with the previous period of analysis $(16.7 \%)$. Only four papers $(6.2 \%)$ contained case studies (e.g., Lekunze \& Strom, 2017) in comparison with $13.9 \%$ in the previous analysis.

Using the classification of published papers by research genre (Borko et al., 2007), it appeared that almost half of all papers (30 or $46.2 \%$ ) did not align with this taxonomy as they mostly contained quantitative descriptive research using the calculation of percentage, descriptive statistics and group differences. Previously in JTES (2005-2014) this group of papers was encountered much less - only in $21.7 \%$ of papers. The largest group fitting the classification of research genre again was papers containing interpretative research ( 21 or $32.3 \%$ ) and this group appeared to be a little larger than in the previous study $(26.1 \%)$. These papers grasp the contextual meaning of phenomena and use the qualitative methodology to comprehend deeper meaning of experience and practice. For instance, Kairiene and Sprindziunas (2016) employed the interviews with students and teachers to deal with the free lunch issue in the context of sustainable schooling, Carbach and Fischer (2017) used the expert interviews to detect how the sustainability reporting process at German schools was evaluated by project managers with regard to its benefits and challenges, but Martinsone and Vilcina (2017) selected the focus group method to expose the teachers' perceptions of the Social Emotional Learning Program in Latvia. Much smaller group with only six papers $(9.2 \%)$ was effect research well represented in paper by Aydin (2016) using quasi-experimental design to prove the advantages of Excel program in teaching basic statistics to pre-service teachers. Previously this group of papers contained a similar number of papers $(8 \%)$. Participative research genre was exemplified in five papers $(7.7 \%)$, for instance, Kravale-Pauliṇa and Oḷehnoviča (2015) depicted the Participatory Action Research organized to involve novice teachers and young people in civic initiatives for securitability in Latvia. For this group this is a 
significant drop in comparison with previous $18.1 \%$. Two papers contained the combination of participative and effect research (Bojāre, 2016; Bojāre \& Skrinda, 2016), while one paper illustrated the design research (Martinsone, 2016) that previously was represented by $10.1 \%$ of papers.

Several emerging trends were detected regarding the type of papers, for example, three papers represented the literature review (Álvarez-García et al., 2015; Krūmiņa \& Lubenko, 2016; Salas-Zapata, Ríos-Osorio, \& Cardona-Arias, 2018); this type of papers was not encountered in the previous period (2005-2014). Also, the usage of secondary data for new empirical analysis was observed for the first time (see Sumaryanta, Mardapi, Sugiman, \& Herawan, 2018).

In general, the quality of qualitative studies in the current period of analysis has improved. In regard to the papers conceived as the qualitative studies (19 papers), the primary method of qualitative data analysis was qualitative content analysis (6 papers), followed by narrative and thematic analysis ( 2 papers each). One paper encompassed the continuous comparative analysis, while five papers just contained the reference to qualitative data collection method or shortly described the general steps of qualitative data analysis. Only three papers did not reflect the research methodology at all, although, the results of these studies indirectly pointed to the qualitative methodology used. All authors (11 papers), detailing on qualitative data analysis, referred to some scholarly source describing the selected method of data analysis.

Out of 17 papers dealing with the quantitative data, four papers comprised the calculation of the percentage while three papers contained the average scores obtained by means of quantitative surveys. Thus, all together $41.1 \%$ of quantitative papers contained the calculation of percentage or average scores, other 10 quantitative research papers contained a statistical analysis using descriptive statistics (7 papers), ANOVA/ Kruscall-Wallis test (6 papers), Student t-criteria/Mann-Whitney criteria (4 papers), Chi-square test ( 3 papers), correlation analysis ( 2 papers), contingency analysis (1 paper). The new promising feature of quantitative research papers is description of psychometric qualities of used instruments (e.g., factor analysis, IRT, reliability analysis, etc.) (5 papers). Majority of the papers containing the statistical analysis applied several procedures of data analysis. To conclude, it seems that also the overall quality of quantitative studies has improved in some aspects.

\section{Discussion}

The discussion section will render answers to three research questions, following the structure of the results section, as well as conceptual approaches to the research in TE for sustainability presented in the introduction to this paper.

\section{Main Bibliometric Indicators (JTES, 2015-2018)}

It should be reminded at the outset that period of JTES performance analysed in this presentation is about twice shorter than the previously analysed period and, therefore, some trends and dynamics well discernable in previous analysis would not be so obvious in the current report. Still, during these past four years one can notice quite significant changes in the host organization of Journal, editorial board as well as editorial team that for the first time in the history of JTES has been extended by invited experts from 
abroad. The new trend that coincides with the end of UN DESD is the leadership of Journal not by one editor-in-chief, but by the team of editors. Rather short period of time from 2015 to 2018 displays the growing dynamics of invited guest editors and number of editors in general. This might designate the relocation and renewal of resources as well as building the closer relationships with UNESCO after the decade, since as the Journal is hosted by UNESCO Chair, JTES could attract the attention of larger players from the research field of TE and those associated with ESD/sustainability research. According to the recommendations in the previous paper on JTES to invite experts in the research methodology of educational research and TE, about 20 new scholars from different countries, among them several highly recognized experts, joined the Editorial Board of JTES. This is a promising sign for the further development of journal aiming toward high quality research.

Impact of Journal has obviously increased during these past years, enticing the rising interest of global community of researchers in TE for sustainability in JTES as well as improved quality of the Journal in general. In tune to the Journal's impact, taking into account the seemingly narrow subject of JTES, also the citation rate of individual papers has grown considerably in comparison with the previous period, thus showing the conceptual value and empirical applicability of the publications in JTES.

All together, the submitted papers came from 29 (previously 26) countries representing all parts of the world. This is an important feature of the Journal illustrating its mission to publish the papers oriented toward the global inclusiveness, similarly as ESD in TE should be implemented not only in several developed countries but also in developing countries, where this movement is highly important. Possibly because of Iranian origins of several editorial team members, the number of publications from Middle East has significantly risen during these past years.

In terms of the recommendation to increase the number of large scale multi-national, multi-institutional and multidisciplinary research, the number of multi-national papers rose about three times in comparison with the previous period, however, none of these papers contained really large scale research on TE for sustainability, although, the attempts to compare the data from several countries are well discernible. The real cause of this scarcity is already mentioned in UNESCO Chair survey of the institutions of TE around the world (MacKeown \& Hopkins, 2014) that found three common problems connected with implementation of ESD in TE, namely, lack of financial resources, awareness or support and human resources. Exactly the same problems might hinder the proliferation of large scale multi-national research papers on this topic. Interestingly, the situation in "general" TE research is not better. According to Sleeter (2014), her analysis of articles published in 2012 in the four TE journals with the highest impact factors in Education and Educational Research shows that only $1 \%$ of articles reported large-scale mixedmethods studies. However, positive changes in JTES have appeared in another direction a larger number of papers are authored by different institutions from single country and as the new trend one can notice a number of transdisciplinary studies involving different type of stakeholders. This is even more promising feature as it concurrently resonates with the philosophical background in several papers discussing peculiarities and applicability of transdisciplinary research in TE. This coincidence can potentially foreground the development of transdisciplinary research approach to TE research in the nearest future. 


\section{Research Paradigms (JTES, 2005-2014)}

Philosophical background. Since the inception of JTES it has been a forum not only for empirical research but also for the philosophical and theoretical elaborations in the field of TE for sustainability, thus, developing both the conceptual models and research paradigms on this subject. The current analysis demonstrates that almost half of published papers contain the references to philosophical conceptualizations similar to those applied in previous volumes of JTES or new ones. The significant increase in comparison with the previous period of analysis can be explained at least by attentiveness of authors to the nature of JTES publications and recognition of one or another theoretical paradigm. However, just a few authors have tried to provide some elaboration of these conceptualizations. This lack of more extensive discussion on conceptual matters in quite large number of papers possibly suggests that intention to name the philosophical theories or specific theoretical concepts could be motivated by a desire to match at least the formal features of JTES publications or deeply seated traditional positivist rationale to ground empirical research only on the most immediate particular theories leading straight to the research questions or hypothesis. The alternative explanation could be based on assumption that not all authors have proper experience with extensive theoretical conceptualizations.

Following these lines, one could apply the metaphor from the paper by Fedosejeva et al. (2018) regarding the hurried salmon evolution, that was used to evaluate the "hurried" human evolution or can be compared with pursuit of human hasty interests in other areas of life. The analysis shows that some authors have been hurried or, probably, hurried themselves to frequent and rather artificial use of the terms like holism, transdisciplinarity and complexity instead of natural growth of understanding in relation to appropriate application of these terms based on extensive theoretical reflections and practical experience. The profuse usage of philosophical terms yet does not determine the value of paper and ability of authors to integrate their philosophical approach with the context of empirical research. Couple of younger authors (doctoral students) apparently were struggling to accomodate the extensive design and wast theoretical background of their doctoral theses in pages allowed for the paper. The ordered semantic waves from Maton's Legitimation Code Theory (Maton, 2014) are rarely noticeable, some authors create the huge "cunami" of theoretical concepts, rising high above the surfice and treatening to trap the readers in deep ocean of ambiguity.

The philosophical terms in scientific papers should not be used deliberately, without clear definition, designation of the specific context of usage and detailed explanation. The authors should avoid from the frequent usage of these terms in contexts not yet fully elaborated in theory, which would ask for another paper to explain the theoretical underpinnings of newly introduced term in detail. The sufficient attention should be paid to differentiation between the usage of philosophical terms in their original meaning (e.g., attributed to models, systems) or as simple adjective (e.g., complex as more catchy than entangled or holistic as more up-to date than whole) without any deeper meaning. As the scrutiny of publications in the present and previous analyses shows, the same thing already has happened with the terms "sustainability" and "sustainable". The authors feel entitled to use the adjective "sustainable" in relation to any noun like writing, timetable, etc., not going into the detailed explanation what is meant by this adjective and if the subject's properties can be really described within the discourse of philosophical and educational contextualization of "sustainability". 
The analysis of philosophical terms used in the analysed papers demonstrates that parallely with the terms already encountered in the previous period (holism, complexity, anthropocentric/non-anthropocentric divide, humanistic philosphy) authors have introduced some new concepts like Anthropocene, transdisciplinarity and ontology. It seems that holistic discourse recently has become self-evident and inavoidable for the interpretation of ESD/sustainable education research in a wide scope of areas. However, it is rather hard to find the exact explanations, definitions of holism or references to previously created theories/ empirical publications, as authors use this term or expressions with this term quite deliberately and, as it has already been mentioned above, attribute it to the large scope of diverse phenomena. The concept of "complexity" was not used so often as holism, though, it seems that this concept was also moving toward its peak time. Yet, the vague usage of this term probably indicates the unintentional wish of some authors for several phenomena really been complex (in original theoretical sense), although they do not provide deeper argumentation and justification for the existence of these “complex" entities.

Pondering on the significant decrease in the usage of anthropocentric/non-anthropocentric divide or critique of anthropocentrism in the analysed papers, it seems that this term has possibly been "substituted" by a new one. Two from three papers, mentioning this term most often, now also contain the numerous references to the concept of Anthropocene, using it as a framework for metaphysical and ontological explanation of unsustainability in society, science, and education. Fedosejeva et al. (2018) suggest that Anthropocene has "now become a phenomenon that demonstrates the unsustainable quality of the ecological, cultural and social relationship of a human being” (p. 158). This "advance of Anthropocene" seems to demonstrate certain shift in thinking from a more philosophically based trend designating the abstract domination of human beings (anthropocentrism) to a more strictly geologicaly delineated "title" for physical and mental space and time where humans live now (Anthropocene). Lack of references to humanism or humanistic education probably illustrates the current trends toward other, more urgent theories or implicates the impending connection of humanism with anthropocentrism in sustainability discourse (Iovino, 2010). It seems that humanistic philosophy, still sometimes applied in traditional learning context, currently has transformed into holistic education and approach (especially in the context of environmental education and ESD) since many important principles of humanistic education (self-regulated learning, integration of rational and emotional, teacher as facilitator, etc.) actually are well discernible in holistic education theory and movement. Gradual emergence of transdisciplinarity not only in the content of published reports, but also in terms of institutional and disciplinary affiliation of authors potentially forecasts the situation in near future when studies conducted within "separated" disciplines will be just one of options to explore the world and its complex problems (Dodig-Crnkovic et al., 2017; McGregor, 2004).

Content of papers: keywords and topics. The changes in the thematics of keywords seem to be sufficiently aligned with the changes in the topics of papers. Two large groups of keywords related to TE/teachers and ESD/sustainability were still well discernible among the keywords, however, this study detected the new large group of keywords related to the psychological processes/phenomena designating learning or behaving within educational environment. One of the possible explanations of this new trend could be the further development of transdisciplinary research approach applied to the teacher professional practice, including also the myriades of psychological phenomena to be 
studied in order to reach sustainability and somehow neglected in the previous period of analysis. Also, the group of keywords related to learning processes and outcomes appears for the first time and includes keywords depicting different types of learning.

Interestingly that in the previous study the group of keywords containing types of schools, students and education was much larger, thus indicating certain reduction in the diversity of educational context reflected in the given period of time. The presence of transdisciplinary approach could be also observed in the rising number of keywords designating different educational stakeholders and their actions.

Two largest groups of topics relate to the professional development of pre-service/ in-service teachers and various school subjects and areas, thus acknowledging more focused content of papers in terms of TE and teaching. Less represented groups of topics, congruent with smaller groups revealed in the previous study, were associated with teachers' views on different issues in education and ESD and school/educational environment, its issues and connection with ESD. Very small number of papers were devoted to preschool education theory and practice, theoretical issues and research in pre-service/in-service TE for ESD, curriculum development and TE program evaluation. Thus, it seems that although three discerned groups of topics were somehow connected with ESD, the largest group still focused on general issues of TE and teaching different subjects. Dealing with the recommendation to decrease the number of papers only marginally connected with TE for sustainability has not been quite succesful, since the number of such papers has slightly risen. Besides, rather high number of papers was discovered focusing neither on teachers nor on ESD/SD. It was observed that some of these authors used the terms like ESD, sustainable education, sustainability or SD in the title of their papers, while in the content of papers these terms were not properly elaborated or were used, as it was enticed before, only as the "imitation" of conceptual deepness (e.g., using "sustainability" instead of "able to be maintained", "kept going", or "continuous, unending, feasible, viable").

A more positive picture appears in charting the topics of JTES (2015-2018) with the help of GAP (UNESCO, 2014). High alignment between the content of papers and priority areas of GAP testifies to the versatility and up-to-date view of authors on topics related to ESD. It was not surprising that the area of capacity building for educators and trainers was represented by the largest number of papers since the journal focuses on the teachers as the main population of study and follows their path starting from student teachers education and training to the most advanced forms of teacher professional development. The next largest area of GAP represented in JTES concerns the transformation of learning and training environments; it is also closely linked to teaching discourse and these papers were mostly related to technological environment, social environment at school or cognitive environment. Considerably smaller number of papers associated with three other priority areas, namely, sustainable solutions at local level, advancement of policy and empowering and mobilizing youth could be exused by the topic area of JTES that at the first glance might not allow for the specific focus on work within local community, in collaboration with politicians or youth.

Much lower alignment was found using the third analytical framework of the topics of papers - processes necessary for effective ESD (Tilbury, 2011). Barely half of the papers matched precisely one or another of these processes. The largest emphasis, in line with the main area of JTES, has been put on the process of teaching/learning including 
also some papers related to active/participatory learning. The process of the whole system engagement suggested by Tilbury (2011) was obviously displayed through the holistic approach to different phenomena (already discussed above), like measuring sustainability competences, analysing views on waste management, searching for educational approaches to sustainable consumption, etc. The implications to the mental wholeness (cognitive and emotional sphere), educational integration (abilities, knowledge, attitudes, dispositions, behaviours, practices), and sustainability integration (social, environmental, economic sectors) reveal the deeply embedded notion of whole system approach in the "cognitive maps" of the authors. Although the processes of collaboration and dialogue as well as curriculum innovation were elaborated only in three papers, the collaborative and dialogical relationships were implicit in content and methodological foundations of much larger number of papers.

Methodological features. Distribution of articles by their research type appeared to be very similar to the previous analysis, with majority of papers representing empirical studies and much smaller groups of theoretical papers and contributions integrating specific theoretical elaborations and empirical research. This proportion is almost identical to the one discovered by Sleeter (2014) in her analytical review on papers in TE journals with the highest impact factors. In terms of methodological preferences in empirical studies, similarly as in the previous study, the qualitative studies were observed more often than quantitative explorations, though, currently the difference in numbers seems to be decreasing and restoring the balance between these approaches. Smallest group of studies, though, showing certain increase in comparison with the previous study, was represented by mixed methods research, probably attaining the attempts of the authors to choose more sophisticated research designs. In comparison with results in Sleeter (2014), where mixed methods studies represented only $4 \%$ of all sample, in the current study this type of research was encountered five times more. However, it should be admitted that in the present set of papers several authors claiming to describe the mixed method study provided mostly the quantitative results. Qualitative part of these studies was either very small, missed the specific details or was completely omitted. Some authors who used the action research or mixed methods research approach described the research methodology and results quite superficially - an issue frequently described in methodological papers on these designs (i.e., Pluye \& Hong, 2014). In a similar vein, for some studies the originally intended research design was too vast and extensive to be properly described in one paper. Thus, it seems that although the quantity of mixed methods research is slowly rising, the quality of this type of research still asks for some improvement, especially in terms of the correspondence between the research idea and conducted research study.

Contrary to the previously exposed idea that case studies would possibly be submitted in large numbers, since the end of UN DESD would ensure the proper conditions for such studies (in terms of collecting rich experience and having sufficient time for implementation), only four papers (from 65) contained case studies - barely half of the contributions discovered in the previous analysis. In study by Sleeter (2014) the small-scale qualitative case studies were reported in $30 \%$ of the studied papers. It could be assumed that previously in some countries case studies were implicitly used as the trademarks of TE success within a framework of formally institutionalized UN DESD guidelines, while after the Decade the need to trumpet the advance of certain institutions has also decreased to some extent. 
In terms of research genre, the prevalence and increase of small scale quantitative descriptive studies (mostly survey research), although, coinciding with the findings in Sleeter (2014), testify to the limited resources and yet undiscovered scientific potential of TE researchers in the field of ESD/sustainability. Some justification of this trend might be searched for in the specific topic of publications, as it has been recognized that study of some novel and previously unexplored topic should begin with smaller scale pilot studies, quantitative or qualitative in their nature, thus collecting the necessary contextual information for the more extensive investigations. Considering the large number of countries (represented in recent volumes of JTES) that just recently joined the global movement of TE toward ESD/sustainability, the large number of small "pilot" studies coming from these countries is also quite reasonable feature. The group of interpretative research was a little larger than in the previous study that showed the gradual growth of recognition for this research genre among the authors of JTES. The number of effect research papers stayed as small as in the previous study, while the drop in participative research and design research could be possibly explained both by the countries - newcomers to the community of researchers in the field of TE for sustainability and by already mentioned lack of resources and potential for these conceptually and methodologically more sophisticated research genres. The first time appeared literature reviews and secondary data analysis illustrate the growing capacity of research field of TE for sustainability.

\section{Conclusions and Recommendations}

At the end, main conclusions, limitations, suggestions for the further research and prospective development of the Journal will be provided together with some implications for the potential authors of JTES.

The inclusive summary of the previous analysis would be the appropriate matter to provide the answers to the research questions and finalise this paper. Thus, there are several significant changes in the main bibliometric indicators featuring papers published in JTES (2015-2018) in comparison with the papers published from 2005 to 2014. The impact of the Journal is obviously increased and citation rate of the Journal and individual papers have grown considerably. Modifications have been observed also in the host organization of the Journal, Editorial Board as well as in editorial team (invited experts from abroad) with the intention to improve the quality and quantity of submissions. Maintaining the multinational character of authorhip, the main focus of submissions has shifted from the North of Europe to the Central and Southern part of Europe, as well as to the Middle East. The number of multinational papers, papers authored by different institutions from single country and transdisciplinary studies involving different types of stakeholders has risen to some extent, thus designating the advance of contemporary trends in research collaboration.

The certain changes showing both improvement and some issues have been observed also in the research paradigms. Speaking about the philosophical background accomodated in published papers, almost half of published papers contain the references to philosophical conceptualizations. Parallely with the terms encountered in the previous period (holism, complexity, anthropocentric/non-anthropocentric divide, humanistic philosphy) some new concepts like Anthropocene, transdisciplinarity and ontology appeared for the first time. Holistic discourse has been applied as natural and rightful part of research in TE for sustainability, anthropocentrism and its critique have been 
substituted by the concept of Anthropocene, while the usage of complexity has been encountered more often than in the previous study, though, in rather vague expressions yet. Humanistic philosophy, sometimes still applicable in traditional learning context, currently has transformed into holistic education and approach. The gradual emergence of transdisciplinarity not only in the content of published reports, but also in the research approaches in submitted papers can also be evaluated as quite positive trend.

As to the quality and quantity of keywords and topics, two large groups of keywords related to TE/teachers and ESD/sustainability were still noticeable, while the group designating the types of schools, students, and education appeared to be much smaller. Two new groups have emerged for the first time, namely, the psychological processes/ phenomena designating learning or behaving within educational environment and learning processes and outcomes. Thus, while the keywords replicating the "title" topic of JTES are still dominating, larger emphasis has been put on the internal psychological processes of students in educational environment, especially, those, connected with learning. Although three discerned groups of topics were connected with ESD (teachers' views on different issues in education/ESD, educational environment, its issues and connection with ESD, and theoretical issues and research in pre-service/in-service TE for ESD), the largest group of papers still focuses on general issues of TE and teaching different subjects. As the positive feature, one can notice the high alignment between the content of papers and priority areas of GAP, the dominant priority area being the capacity building for educators and trainers. Analytical framework for the topics of papers - processes necessary for effective ESD was applied with much less success as barely half of the papers matched precisely one or another of these processes, the largest emphasis was put on the process of teaching/learning including also some papers related to active/participatory learning.

Considering the methodological features of papers, distribution of articles by their research type is very similar to the previous analysis, with majority of papers representing empirical studies and much smaller groups of theoretical papers and contributions integrating specific theoretical elaborations and empirical research. The analysis shows the balance of quantitative and qualitative studies, the growth of mixed method studies, yet not with the perfect quality, decreasing number of case studies and the prevalence and increase of small scale quantitative descriptive studies (mostly survey research). The group of interpretative research was a little larger than in the previous study, while the number of effect study stayed as small as in the previous analysis. Participative research and design research have been represented with smaller numbers than in the previous period of JTES.

Focusing on the recommendations and suggestions elaborated in the previous study (Pipere et al., 2015), it seems that, to some extent, all of them have been implemented and considered in the bibliometric characteristics of the Journal and its publications. Thus, the Journal has maintained the diversity of research performed in different parts of the world and preserved the unique features of publications, in general, maintaining the good standards of academic writing. However, there seems to be a large potential for the improvement of academic writing in terms of submissions coming from the countries beginning their general movement toward sustainability-oriented TE after the end of UN DESD.

The number of multi-national and multi-institutional research has significantly risen, though, this is not quite large-scale research. Also, the new transdisciplinary 
approach has been introduced not only in authorship of papers representing various stakeholders, but also in the philosophical background of the papers.

In general, the quality of methodological dimensions of contributions in these past four years of JTES has slightly improved. This can be proved by several indications in relation to both quantitative and qualitative studies like more appropriate and detailed presentation of qualitative data analysis methods, increasing number and quality of more advanced statistical data analysis methods and description of psychometric qualities of used instruments. Regarding the mixed methods studies, although the quantity of research has increased, the quality of submissions needs to be improved yet.

The recommendation to strengthen the Editorial Board of JTES seems to be even overachieved since during the analysed period radical changes have been made not only in the Editorial Board that has been expanded by a large number of new qualified members, but also in host organization and editorial team of JTES. The Journal is hosted now by the UNESCO Chair and growing numbers of editorial team and Editorial Board members that hopefully will serve to the further development of JTES.

Considering the Journal's response to the call from the UNESCO GAP (UNESCO, 2014) to focus research on issues not fully resolved or even increasing during DESD, this study shows the very close alignment between the content of JTES' (2015-2018) papers and priority areas of GAP, the two dominant priority areas being the capacity building for educators and trainers and transformation of learning and training environments.

The suggestion to decrease the number of papers only marginally connected with TE for sustainability was not yet implemented to a full extent, since the number of such papers has slightly risen in past four years.

Several limitations should be admitted for this study: First of all, since the analysed period of time of JTES is much shorter than the previous one and the global context has changed, the interpretation of differences between those two periods should not be done in straightforward manner. Moreover, this paper lacks a more detailed analysis for the theoretical underpinnings of research on TE for sustainability that could make it look more monolithic, though much longer. Subjectivity still prevails in performing the coding for bibliometric analysis and interpretation of research paradigms, since the analysis was completed by the author, having rich experience with JTES as the editorin-chief, guest editor, Editorial Board member, and author. In comparison with the previous paper, this paper does not include the analysis of all those criteria interpreted in the previous presentation, focusing only on the main ones. However, one limitation mentioned in the previous paper - lack of deeper exploration of sample articles from JTES, currently has been partly eliminated by a more extensive analysis of philosophical background of papers, providing references and citations from papers.

Concluding the work on this analysis, some suggestions would help to better envision the avenues for exploration while assisting in further development of research and publication on TE for sustainability. For instance, a more detailed analysis of sample articles from JTES to provide suggestions for high quality academic writing and elaborated examples for some research themes could also be of interest for potential authors of the Journal. Also, the potential authors of next JTES reviews would focus the whole paper either on the bibliometric analysis or analysis of research paradigm for the Journal. Other enticing possibility would be the comparison of bibliometric criteria or research paradigms coming from different parts of the world or further development of research 
paradigm analysis, using qualitative content analysis and providing sample articles that illustrate a peculiar research paradigm.

The conducted study together with provided conclusions leads to several recommendations to the Journals' editorial team and also to the potential authors of JTES. The first group of recommendations could be more appropriate for the editors and reviewers of journal, however, some of these suggestions could be of interest to the authors of JTES. Thus, it seems appropriate to suggest that in future JTES should:

- pursue the regular practice of inviting guest-editors and publishing special volumes, thus enhancing the geography of publications and quality of submissions;

- keep the general orientation of papers in line with the normative guidelines by UNESCO, though, considering the unique and specific niche of the Journal;

- focus more on publishing papers clearly related to the topic of TE for sustainability, targeting both the teachers and/or their work environment and ESD issues in a single paper;

- support the development of multi-national, multi-institutional, multidisciplinary, interdisciplinary and transdisciplinary research enhancing the scale of such research;

- improve the quality of academic writing - mostly for the submissions coming from the countries beginning their general movement toward sustainabilityoriented TE after the end of UN DESD;

- further the quality of methodological dimensions of published papers, attracting the authors with more sophisticated research designs, especially with welldesigned large-scale mixed methods research, advancing the genres of effects research, design research and participative research.

Following suggestions based on the analysis provided in this paper could be especially helpful for individual authors:

- In terms of research genre, the number of small-scale quantitative descriptive studies (mostly survey research) need to be balanced with more advanced research genres;

- The research collaboration should be implemented more actively, for instance, researchers from different geographic locations or higher education institutions, implementing the accurate planning and coordinating, could perform linked small-scale studies using the same methodological approaches (Sleeter, 2014).

- Deep understanding of educational philosophy and theoretical conceptualization in education and pedagogy would help to make them more explicit in writing about TE for sustainability.

- The philosophical/theoretical concepts should be used with larger awareness, providing clear definitions and description of the specific context of usage.

- The integration of terms like ESD, sustainable education, sustainability or SD in the title of paper obliges the authors to reveal the theoretical background of used terms and specific context of their usage in the given paper.

- Whatever research design is used in the study, it needs to be properly described; also, it is better to plan for smaller research with its subsequent adequate reflection in a paper rather than suggesting the sophisticated research design at the outset, being able to illustrate only small part of the conducted study. The paper should demonstrate the congruence between the research idea and conducted/described study. 
Sometimes to start something from the scratch is more easier than to maintain the quality and quantity of the process in a longer period of time. Thus, in future JTES needs to build on the past success, so that the good start is not lost. Hopefully, this analysis and recommendations will be advantageous for JTES editorial team and Editorial Board members as well as the potential authors of JTES, thus supporting the advancement of the whole research field of TE for sustainability in its mission to explore for the future.

\section{References}

Álvarez-García, O., Sureda-Negre, J., \& Comas-Forgas, R. (2015). Environmental education in pre-service teacher training: A literature review of existing evidence. Journal of Teacher Education for Sustainability, 17(1), 72-85.

Andić, D., \& Tatalović Vorkapić, S. (2017). Teacher education for sustainability: The awareness and responsibility for sustainability problems. Journal of Teacher Education for Sustainability, 19(2), 121-137.

Anyolo, E. O., Karkkainen, S., \& Keinonen,T. (2018). Implementing education for sustainable development in Namibia: School teachers' perceptions and teaching practices. Journal of Teacher Education for Sustainability, 20(1), 64-81.

Aydin, S. (2016). Using Excel in teacher education for sustainability. Journal of Teacher Education for Sustainability, 18(2), 89-104.

Badjanova, J., Pipere, A., \& Iliško, Dz. (2017). Gender identity of students and teachers: Implications for a sustainable future. Journal of Teacher Education for Sustainability, 19(2), 138-153.

Bell, D. V. J. (2016). Twenty-first century education: Transformative education for sustainability and responsible citizenship. Journal of Teacher Education for Sustainability, 18(1), 48-56.

Besong, F., \& Holland, C. (2015). The Dispositions, Abilities and Behaviours (DAB) Framework for profiling learners' sustainability competencies in higher education. Journal of Teacher Education for Sustainability, 17(1), 5-22.

Biasutti, M., De Baz, T., \& Alshawa, H. (2016). Assessing the infusion of sustainability principles into university curricula. Journal of Teacher Education for Sustainability, $18(2), 21-40$.

Bikse, V., Lusena-Ezera, I., Rivza, B., \& Volkova, T. (2016). The transformation of traditional universities into entrepreneurial universities to ensure sustainable higher education. Journal of Teacher Education for Sustainability, 18(2), 75-88.

Bojāre, I. (2016). Autonomous learning for English acquisition in blended e-studies for adults within the context of sustainable development. Journal of Teacher Education for Sustainability, 18(1), 111-126.

Bojāre, I., \& Skrinda, A. (2016). Transformation of the system of values of autonomous learning for English acquisition in blended e-studies for adults: A Holistic Fractal Model. Journal of Teacher Education for Sustainability, 18(2), 119-134.

Borko, H., Liston, D., \& Whitcomb, J. A. (2007). Genres of empirical research in teacher education. Journal of Teacher Education, 58(1), 3-11.

Briede, L. (2016). The relationship between mathematics teachers teaching approaches and 9 th grade students mathematical self. Journal of Teacher Education for Sustainability, 18(1), 34-47. 
Carbach, E., \& Fisher, D. (2017). Sustainability reporting at schools: Challenges and benefits. Journal of Teacher Education for Sustainability, 19(1), 69-81.

Ciuladiene, G., \& Kairiene, B. (2017). The resolution of conflict between teacher and student: Students' narratives. Journal of Teacher Education for Sustainability, 19(2), 107-120.

Dodig-Crnkovic, G., Kade, D., Wallmyr, M., Hostein, T., \& Almer, A. (2017). Transdisciplinarity seen through information, communication, computation, (inter-)action and cognition. In M. Burgin \& W. Hofkirchner (Eds.), Information studies and the quest for transdisciplinarity: Unity through diversity (pp. 217-262). World Scientific Publishing.

Eernstman, N., \& Wals, A. E. J. (2013). Locative meaning-making: An arts-based approach to learning for sustainable development. Sustainability, 5, 1645-1660.

Eslamian, H., Jafari, S. E. M., \& Neyestani, M. R. (2017). Investigating the effect of teaching aesthetic skills to faculty members on development of their effective teaching performance. Journal of Teacher Education for Sustainability, 19(2), 90-106.

Fink, A. (2009). Conducting research literature reviews. From the Internet to paper ( $3^{\text {rd }}$ Ed.). Thousand Oaks: Sage Publications.

Fedosejeva, J., Boče, A., Romanova, M., Iliško, Dz., \& Ivanova, O. (2018). Education for sustainable development: The choice of pedagogical approaches and methods for the implementation of pedagogical tasks in the Anthropocene age. Journal of Teacher Education for Sustainability, 20(1), 157-179.

Geng, G., Midford, R., \& Buckworth, J. (2015). Investigating the stress levels of early childhood, primary and secondary pre-service teachers during teaching practicum. Journal of Teacher Education for Sustainability, 17(1), 35-47.

Ichinose, T. (2017). An analysis of transformation of teaching and learning of Japanese schools that significantly addressed education for sustainable development. Journal of Teacher Education for Sustainability, 19(2), 36-50.

Iovino, S. (2010). Ecocriticism and a non-anthropocentric humanism. Reflections on local natures and global responsibilities. In L. Volkmann, N. Grimm, I. Detmers, \& K. Thomson (Eds.), Local natures, global responsibilities (pp. 29-53). Amsterdam: Rodopi.

Jirgensons, M., \& Kapenieks, J. (2018). Blockchain and the future of digital learning credential assessment and management. Journal of Teacher Education for Sustainability, 20(1), 145-156.

Jonāne, L. (2015). Using analogies in teaching physics: A study on Latvian teachers'views and experience. Journal of Teacher Education for Sustainability, 17(2), 53-73.

Jurgena, I., Cēdere, D., \& Keviša, I. (2018). The prospects of transdisciplinary approach to promote learners' cognitive interest in natural science for sustainable development. Journal of Teacher Education for Sustainability, 20(1), 5-19.

Howard, P. (2015). Digital citizenship in the afterschool space: Implications for education for sustainable development. Journal of Teacher Education for Sustainability, 17(1), 23-34.

Kabadayi, A. (2016). Suggested in-service training model based on Turkish preschool teachers conceptions for sustainable development. Journal of Teacher Education for Sustainability, 18(1), 5-15.

Kairiene, B., \& Sprindziunas, A. (2016). Social equality as groundwork for sustainable schooling: The free lunch issue. Journal of Teacher Education for Sustainability, 18(1), 127-139. 
Kevin wan utap anyi, Zainab, A. N., \& Anuar, N. B. (2009). Bibliometrics studies on single journals: A review. Malaysian Journal of Library and Information Science, $14(1), 17-55$.

Kolbe, K. D. (2015). Knowledge, attitudes and behaviour regarding waste management in a grammar and a comprehensive school in England: Results from a school questionnaire. Journal of Teacher Education for Sustainability, 17(1), 58-71.

Korsun, I. (2017). The formation of learners' motivation to study physics in terms of sustainable development of education in Ukraine. Journal of Teacher Education for Sustainability, 19(1), 117-128.

Kravale-Pauliņa, M., \& Oḷehnoviča, E. (2015). Human securitability: A participatory action research study involving novice teachers and youngsters. Journal of Teacher Education for Sustainability, 17(2), 91-107.

Krūmin,a, A. A., \& L,ubenko, J. (2016). Web-based intervention for developing longterm health literacy of individuals: Possibilities and limitations. Journal of Teacher Education for Sustainability, 18(1), 69-83.

Lekunze, L. M. G., \& Strom, B. I. (2017). Bullying and victimisation dynamics in high school: An exploratory case study. Journal of Teacher Education for Sustainability, 19(1), 147-163.

MacKenzie, S. B. (2003). The dangers of poor construct conceptualization. Journal of the Academy of Marketing Science, 31, 323-326.

Mammadova, A. (2017). Education towards urban sustainability: Lessons learned from the welfare business models of Kanazawa city, Japan. Journal of Teacher Education for Sustainability, 19(2), 154-164.

Martinsone, B. (2016). Social Emotional Learning: Implementation of sustainabilityoriented program in Latvia. Journal of Teacher Education for Sustainability, 18(1), 57-68.

Martinsone, B., \& Vilcina, S. (2017). Teachers' perceptions of sustainability of the social emotional learning program in Latvia: A focus group study. Journal of Teacher Education for Sustainability, 19(2), 5-20.

Maton, K. (2014). Building powerful knowledge: The significance of semantic waves. In B. Barrett \& E. Rata (Eds.), Knowledge and the future of the curriculum: International studies in social realism (pp. 181-197). London: Palgrave Macmillan.

Mauser, W., Klepper, G., Rice, M., Schmalzbauer, B. S., Hackmann, H., Leemans, R., \& Moore, H. (2013). Transdisciplinary global change research: The co-creation of knowledge for sustainability. Current Opinion in Environmental Sustainability, 5, 420-431.

McGregor, S. L. T. (2004). The nature of transdisciplinary research and practice. Kappa Omicron Nu Human Sciences Working Paper Series. Retrieved from: http://www. kon.org/hswp/archive/transdiscipl.html

McKeown, R., \& Hopkins, C. (2014). Teacher education and education for sustainable development: Ending the DESD and beginning the GAP. Toronto: York University.

Miedema, S., \& Bertram-Troost, G. (2015). The challenges of global citizenship for worldview education. The perspective of social sustainability. Journal of Teacher Education for Sustainability, 17(2), 44-52.

Okeke, C. I., \& Mtyuda, P. N. (2017). Teacher job dissatisfaction: Implications for teacher sustainability and social transformation. Journal of Teacher Education for Sustainability, 19(1), 54-68. 
Petticrew, M., \& Roberts, H. (2009). Systematic reviews in the social sciences. A practical guide ( $8^{\text {th }}$ Ed.). Malden: Blackwell Publishers.

Pipere, A., Veisson, M., \& Salite, I. (2015). Developing research in teacher education for sustainability: UN DESD via the Journal of Teacher Education for Sustainability. Journal of Teacher Education for Sustainability, 17(2), 5-43.

Pluye, P., \& Hong, Q. N. (2014). Combining the power of stories and the power of numbers: Mixed methods research and mixed studies reviews. Annual Review of Public Health, 35(1), 29-45.

Raus, R. (2016). Modelling a learning journey towards teacher ecological self. Journal of Teacher Education for Sustainability, 18(2), 41-52.

Reid, E., \& Horváthová, B. (2016). Teacher training programs for gifted education with focus on sustainability. Journal of Teacher Education for Sustainability, 18(2), 66-74.

Regolini, A., \& Jannes-Ober, E. (2013). A bibliometric study of Informing Science: The International Journal of an Emerging Transdiscipline. Informing Science: the International Journal of an Emerging Transdiscipline, 16, 117-130.

Salas-Zapata, W. A., Ríos-Osorio, L. A., \& Cardona-Arias, J. A. (2018). Knowledge, attitudes and practices of sustainability: Systematic review 1990-2016. Journal of Teacher Education for Sustainability, 20(1), 46-63.

Salìte, I., Drelinga, E., Iliško, Dz., Oḷehnoviča, E., \& Zariņa, S. (2016). Sustainability from the transdisciplinary perspective: An action research strategy for continuing education program development. Journal of Teacher Education for Sustainability, $18(2), 135-152$.

Salīe, I., \& Pipere, A. (2007). Journal of Teacher Education and Training: Deepening action research. In R. McKeown (Ed.), Good practices in teacher education institutions (pp. 41-46). ESD in Action, Good Practices No. 1 - 2007, UNESCO Education sector.

Sleeter, C. (2014). Toward teacher education research that informs policy. Educational Research, 43(3), 146-153.

Stanszus, L. et al. (2017). Education for sustainable consumption through mindfulness training: Development of a consumption-specific intervention. Journal of Teacher Education for Sustainability, 19(1), 5-21.

Stašulāne, A. (2017). Factors determining children and young people's well-being at school. Journal of Teacher Education for Sustainability, 19(2), 165-179.

Sumaryanta, Mardapi, D., Sugiman, \& Herawan, T. (2018). Assessing teacher competence and its follow-up to support professional development sustainability. Journal of Teacher Education for Sustainability, 20(1), 106-123.

Šipilova, V., Ostrovska, I., Jermolajeva, E., Aleksejeva, L., \& Oḷehnovičs, D. (2017). Evaluation of sustainable development in rural territories in Latgale region (Latvia) by using the conception of smart specialization. Journal of Teacher Education for Sustainability, 19(1), 82-105.

Thanuskodi, S. (2010). Journal of Social Sciences: A bibliometric study. Journal of Social Sciences, 24(2), 77-80.

Tilbury, D. (2011). Higher education for sustainability: A global overview of commitment and progress. In GUNI (Ed.), Higher education in the world 4. Higher education's commitment to sustainability: From understanding to action (pp. 18-28). GUNI: Barcelona. 
Torraco, R. (2005). Writing integrative literature reviews: Guidelines and examples. Human Resource Development Review, 4, 356-367.

Ulavere, P., \& Tammik, A. (2017). Value education in Estonian preschool child care institutions. Journal of Teacher Education for Sustainability, 19(1), 129-146.

UNESCO (United Nations Educational, Scientific and Cultural Organisation). (2005). Guidelines and recommendations for reorienting teacher education to address sustainability. Education for Sustainable Development in Action Technical Paper No. 2, UNESCO Education sector.

UNESCO (United Nations Educational, Scientific and Cultural Organisation). (2014). Roadmap for implementing the Global Action Programme in Education for Sustainable Development. Paris: UNESCO.

Whittemore, R., \& Knafl, K. (2005). The integrative review: updated methodology. Journal of Advanced Nursing, 52(5), 546-553.

Wright, T., \& Pullen, S. (2007). Examining the literature: A bibliometric study of ESD journal articles in the Education Resources Information Center Database. Journal of Education for Sustainable Development, 1(1), 77-90.

Correspondence concerning this paper should be addressed to Anita Pipere, Professor, Institute of Humanities and Social Sciences, Center of Sustainable Education, Daugavpils University, Parādes iela 1, Daugavpils, LV-5401, Latvia. Email: anita.pipere@du.lv 